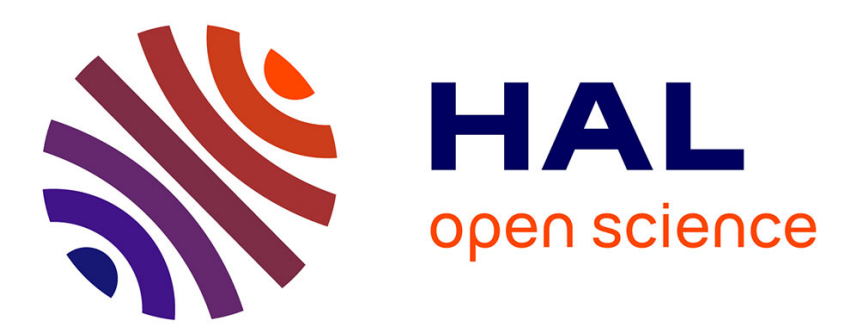

\title{
Drawing on Human and Plant Correspondences on the Rai Coast of Papua New Guinea
}

\author{
Porer Nombo, James Leach, Urufaf Anip
}

\section{To cite this version:}

Porer Nombo, James Leach, Urufaf Anip. Drawing on Human and Plant Correspondences on the Rai Coast of Papua New Guinea. Anthropological Forum: A Journal of Social Anthropology and Comparative Sociology, 2021, The Art of Gardens: Views from Melanesia and Amazonia, Guest Editors: Jean Mitchell and Lissant Bolton, 31 (4), pp.352-376. 10.1080/00664677.2021.1990012 . halshs-03430816

\section{HAL Id: halshs-03430816 \\ https://shs.hal.science/halshs-03430816}

Submitted on 6 Jan 2022

HAL is a multi-disciplinary open access archive for the deposit and dissemination of scientific research documents, whether they are published or not. The documents may come from teaching and research institutions in France or abroad, or from public or private research centers.
L'archive ouverte pluridisciplinaire HAL, est destinée au dépôt et à la diffusion de documents scientifiques de niveau recherche, publiés ou non, émanant des établissements d'enseignement et de recherche français ou étrangers, des laboratoires publics ou privés. 


\title{
Drawing on Human and Plant Correspondences on the Rai Coast of Papua New Guinea
}

\author{
Porer Nombo
}

Reite Village, Mot 1. District, Rai Coast, Madang, Papua New Guinea

James Leach

Aix Marseille Université, CNRS, EHESS, CREDO UMR 7038, Marseille, France

Urufaf Anip

Marpungae Village, Mot 1 District, Rai Coast, Madang, Papua New Guinea

\begin{abstract}
In the hinterland of the Rai Coast, technical gardening practice is also ritually and spiritually charged daily activity to ensure the movement of foods and deities from the garden to the village. To approach this 'art of gardening' we attend to process and transformation and to how garden produce becomes the matter of beautiful forms. With reference to new pencil drawings of gardens we explore the aesthetic of the garden's embodiment of myth and history. The drawings and text provide a detailed documentation of lowland taro cultivation. The processes illustrated are at one and the same time attending to plant and human wellbeing. The notion of 'grace' from Gregory Bateson's writings is introduced. Highlighting the connections drawn between spirits and people and plants, we consider an immanence of life in mythic, human, and vegetable reproduction.
\end{abstract}

Keywords: Gardens; Taro; Yam; Deities; Aesthetics

\section{Introduction: Drawing gardens}

This paper was written alongside companion drawings of gardens made by Porer Nombo and Urufaf Anip in January 2019 as part of a discussion between the three of us about what Reite people find beautiful about their gardens. The writing of the substantial sections was drafted together with each of us adding thoughts and information to a growing description of the processes of gardening as it is practiced in Reite village on the Rai Coast of Papua New Guinea. The academic author added the introduction and the conclusion later on in the light of our joint understandings. The drawings are a route into the garden and help in comprehending the correspondence and pattern that Reite gardeners, on the Rai Coast of Papua New Guinea, assume. Labour is also apparent in the drawings, as in the gardens. In the 
case of the drawings, it was the labour of spending hours using unfamiliar tools (pencils) to achieve an always exploratory, 'is this good enough, is this growing well'?

The anthropologist Gregory Bateson developed a notion of 'style' which he saw as linked to 'grace' (1972, 128-9). 'Grace' for Bateson describes an achievement in presenting visually, and in a 'beautiful' and 'skilful' way, an integrated sum total of what is vital to human life. Art, he argues, can demonstrate 'psychic integration' $(1972,129)$. The 'achievement' of grace in (non-Western) art is apparent when certain sorts of habits or skills are transplanted from the conscious level into the unconscious $(1972,308,470)$. These skills become accessible through art as the interface between the unconscious and the conscious, and reveal the particular patterns of transformation that are central to a culture. Bateson was not interested in messages, but in the principles of transformation which he believed could be appreciated by those beyond the particular style utilised. According to Bateson, there is a 'redundancy of information' in the structured patterns and the restraint of variability in skilled visual presentation that allows such 'art' to define the context of practice. In his terms, the Reite art of gardening works with the transformative patterns linking human life -biological and social life -- to the life of the key crops, taro and yam, and thus makes the real garden also an image with 'grace' as he would see it. ${ }^{\text {i }}$

The introduction of Bateson's ideas to this paper requires explanation as his text itself was not accessible to Porer and Urufaf other than through translation by James. Stepping back for a moment, this is also an opportunity to clarify something further about the way the paper was written. The approach taken is to represent faithfully a long standing and mutually interesting conversation between the authors about the processes and the effectiveness of aspects of Reite people's practice. The authors brought different things to the mutual recognition and elaboration. The anthropologist/author here is not a novice to taro gardening or its ritual elements, having worked both physically (in gardens) and intellectually (clarifying, understanding and discussing) aspects with a previous, and now this generation, of Reite gardeners. Porer and Urufaf are interested in ways to make their skill and artistry apparent to those with little idea of its existence. 'Discussion' is a key term here. Porer is less interested in furnishing data than in drawing on what he can from the conversation with an outsider for his own understanding and projection. The approach is mutual. The academic author brought some ideas from a re-reading of Bateson to the conversation about gardens, beauty, and the drawings, in a way that Porer and Urufaf found potentially effective in the 
emergent picture of their practice. That is why several theories from beyond Reite appear in the text.

In discussing correspondence and skill, James introduced ideas from Bateson to our conversation as a possible approach. We found that thinking about what is unarticulated but still effective, what is latent in gardening processes but still formative of them, to be mutually beneficial. Similarly with Strathern, we found the focus on process and transformation productive. In this, the paper and the drawings are both experimental, awkward (there is no disguising the actual writer), and working towards a synthetic and dialogic form of text. It is also why the drawings are key in an unexpected way. They are a new form of contemporary engagement, elicited in answering a novel question: how to visually explain to outsiders what a garden has to look like to make it effective. Commenting upon the ways to enhance the growth of important crops in words that refer at the same time the upbringing of and care for children, the text forms an entity with the respective drawings. There is no doubt that on the whole we are dealing here with the 'art of gardening' as practiced by Reite people, bringing the unconscious understanding of relationships and transformation to the fore, quite in line with Bateson's model of an analysis.

\section{The Drawings}

The strange symmetry and the detail in the drawings offer a version of the satisfaction of gardening in perhaps the old sense of that term. That is, the Latin root of 'satisfy' satisfacere means 'discharge fully, comply with, make amends,' literally 'do enough,' from satis 'enough'. ii

Porer is a garden-artist. His drawings of the garden are personal, situated, expressive, connecting and vibrant with the moment. His use of pencils to make marks on paper is informed by experience and tactile engagement with soil and insect and leaf and root. The marks are delicate yet demonstrate both a captivating dynamism and a gentle sweetness. They are full of life, full of texture and weight. Urufaf's drawings have a different lighter style with tension, tightness, precision, and balance. They are informative about the specific forms of garden design and also evidence the care and concern these people have for plants and how they appear. 


\section{[[PLEASE INSERT FIGURE 1 ABOUT HERE]]}

Figure 1 : Porer Nombo. January 2019. A mature taro garden, showing the fat taro corms, the yam tubers under the earth, gourds, beans, and bananas ready for harvest. The kaap sernung in this picture is 'tupong aluling', the spirit pool at Samat matakaring where taro was revealed (see below). It looks like a magnifying glass in the middle, illuminating, with clear light beneath. This magnifying glass is also the kaap sernung, the spirit path into and out of the garden. Where they come and go, and that is (also) the road for the gardener. Porer talks of the way the road leads into each section. It is a practical road, and a magnifying clarity, and is opened or closed for the taro to enter and leave. It is an image of looking after, not controlling. (NB. the 'baby' taro, ginger, and leaves on the path from the garden, elaborated in the text.)

\section{[[PLEASE INSERT FIGURE 2 ABOUT HERE]]}

Figure 2: A newly planted taro garden, showing the shape of the kaap sernung 'kau atting' (crayfish legs). Porer Nombo. January 2019.

\section{[[PLEASE INSERT FIGURE 3 ABOUT HERE]]}

Figure 3: Urufaf Anip's drawing of the tupong aluling at 'Samat matakaring' design.

\section{[[PLEASE INSERT FIGURE 4 ABOUT HERE]]}

Figure 4: Urufaf's Anip's drawing of the 'wating', the central shoot, or 'eye' of the garden.

\section{[[PLEASE INSERT FIGURE 5 ABOUT HERE]]}

Figure 5: The Marpungae version of the kaap sernung design by Urufaf.

\section{[[PLEASE INSERT FIGURE 6 ABOUT HERE]]}

Figure 6: Urifaf's 'Key' to his drawings.

\section{[[PLEASE INSERT FIGURE 7 ABOUT HERE]]}

Figure 7: Some common garden foods with vernacular names by Urufaf.

\section{The satisfaction of cultivation or the cultivation of satisfaction?}


Gardens have long been a subject of aesthetic appreciation in leisured European life. The appreciation shares much in its underlying principles with the appreciation of western 'art'. Gardens, like art as 'high culture' (Wagner 1975, 21) often demonstrated humanities' attainments and artifices. Appreciation was not dependent upon utility. In this vein, processes of use have historically been denigrated by a culture in which leisure, and time for the cultivation of the arts, has a prestige value. Quotidian and everyday are seen as necessities, whereas the cultivation of tastes and appreciation is a sign of civilisation and of humanity transcending nature. In fact, the control over nature is definitive of the European enlightenment, scientific and technical project (see Leach and Davis 2012).

Perhaps we could call this 'the satisfaction of cultivation'? To see cultivation on a grand scale is to see and appreciate the finer aspects of human transcendence. Cultivation of the grand gardens of the stately homes of Europe showed that nature can be brought under the taming influence of the civilised, and that there is wealth and leisure enough to achieve highly aesthetic forms. A condition of this is that gardens are beautiful, not that they are useful.

Surely most Melanesian gardens though are all about subsistence? And that is a practical and quotidian matter. Why would anyone who struggles to produce their own food (to live) be concerned with the look or aesthetic of the garden?

The words that follow in our paper seem to challenge the very notion that the practical efforts of subsistence are not also the very actions and practices that bring satisfaction of a most sublime and potent kind. Although 'satisfaction' has an unfortunate modern connotation of self-regard that is inappropriate here, thinking of its original meaning, perhaps we might call this the 'cultivation of satisfaction'? To give, and to do enough: Just how important giving is will become clear as we proceed.

We took the chance to record detailed information that links practice to history, and history to myth and power. These considerations are not ancillary to cultivation. They are what is brought into being as the substance of plants and bodies that are already located within the kinship and spiritual projects of Reite gardeners. To follow myth is to recreate the world in the human form of gardens. It is thus to grow the human and mythic shape of what it is to be yam, taro, person. Knowing myth makes ritual of everyday labour.

\section{Ritual, art, and process}


Anthropologists of Melanesia have long noted the connection between 'ritual' and 'art' in the region. Consideration of ritual objects as 'art' and a concern with their aesthetic value (while wholly understandable) may also have been something of a distraction from comprehending their effect in process. Ironically, while western art became more and more abstract, primitive art was being rescued from its categorisation as 'primitive' by appreciating it for its formal and aesthetic qualities (Picton 1992). It could be understood through interpretive analysis, referring to the symbolism of the work.

One effect of this approach was a proliferation of interpretation to the extent that led some commentators to suggest that the focus on 'meaning' had a hyperbolic effect (Weiner 1995). This was seen in at least two ways. On the side of the analyst, a focus on aesthetics (symbolic interpretation) produced proliferating accounts of the meaning of objects which might never be complete, depending on the theoretical or interpretive framework of the interpreter. Contrastingly, the creators themselves were often reticent or even silent about meaning, focussing instead on effect.

Garden crops in Reite are an example of a process-oriented aesthetic of life and vitality that looks to what animates and transforms people and their bodies. The meaning is very much in the doing, the growing, the consumption. It is also possible to see this as a kind of artistry, once certain cultural biases are made explicit and an attempt is made to circumvent them.

As art appreciation tends to gravitate towards the intellectual and reified rather than understanding the making and use of objects, in some ways it has deflected attention from what the making and use of objects does in relations between people, the transformations it encodes. As Strathern $(2013,23)$ has it,

[o]ften such objects are thought of as things or artefacts ... As we find, however, many of them point to other objects that do not take the form of 'things' at all. ... If we are to retain the centrality of 'objects' they have to appear as rather more than things or artefacts or art.

Perhaps, Strathern suggested, the analyst's obsession with meaning and meaning making obscured the way these objects figured in people's practices: 
we should not look at the objects as items on display but look at the work that goes into making them, that is, all the ritual activity that makes their making necessary. (24)

It is hard not to be surprised, in retrospect, at the lack of attention to the art of gardening. One can only put this down to a cultural weight put on the aspects that speak of transcendent or intellectual and spiritual truths and pursuits (Wagner 1975, 22), and thus overlook or even denigrate the living miracles that are also everyday processes. This is a dismissal of subsistence gardening as uncomplicated. However, there is artistry in producing garden food in Melanesia in that '[i]ts valuation is such that it appears to be used everywhere to create, maintain and manipulate social relationships.' (Young 1971, 146)

Unsurprisingly in Porer and Uru's account, it is the origin, and thus reason for taro gardens to be planted as they are, which came first. Tracing origin is the source of connection between what people did in the past and what they (continue to) do now. Origin is related in myth. Knowing where taro came from is also knowing who gave it to whom. Relating a myth is not knowing just a narrative, it is making a claim to personal connection. That personal connection brings history, myth, and power into current action.

\section{Patuki reveals taro}

Patuki is a Nekgini word for 'story', 'mythic hero', 'deity', and 'knowledge'. Thus the narrative of a tale is patuki, the characters within it are patuki, and the names and knowledge it contains or is, are also 'patuki'.

\section{Porer's account begins here.}

All the forms of food our ancestors had were lodged in the branches of a huge tree to the west of where we live. This tree also contained the elements of our material culture and spiritual paraphernalia. At the foot of the tree, a young boy found fruit that was incredibly sweet to taste. As he ate it, he heard music coming from in the branches of the tree. At that time, people survived by eating worms and grubs, and boiling stones with wild ginger and drinking the resulting soup. They decided to cut the tree to get at these good things, but when they cut it, it fell to the east of them and dropped foods in our lands. As it continued to fall further, it 
dropped the musical paraphernalia of our male cult in the next language group on the other side of the Mot river. ${ }^{\text {iii }}$

Taro, yam, and bananas came into our lands at this time.

These items were patuki; that is, they were kinds of being or spirit that then resided in our land. They hid in the earth or in caves and streams, some became animals or plants and hid themselves. The people at the time had no idea they were there. They had been afraid when the tree fell but remained unaware of the taste of these things that were now in their lands. We call these beings 'patuki'.

The taro patuki recognised that the people who lived here had nothing to eat. His voice was musical, and this music called to people. A man from Reite often heard the voice of this patuki when he went to the stone that they used for sharpening their stone axes. The taro patuki sat by the stone by the pool where he resided, a place called Samat Matakaring ${ }^{\text {iv }}$, and sang in the voice of what we now call the 'tambaran' in Tok Pisin -- the spirit voices produced by the male cult. The man sharpening his axe found him there. The taro man told him they would go to his house, but the man could not enter the deep pool in the stream. 'Taro' gave a bean to the man and they both chewed it and spat it onto the water, which dried up as a result. They went into the pool and he found a house under the level of the water. Inside, he saw taro piled up. Patuki told him to sit down and he began to prepare taro and to cook. He took wing-beans from their pod. ${ }^{\text {vi }}$ He prepared salt from salt wood, ${ }^{\text {vii }}$ and peeled taro. The beans he fried in a shard of clay pot, and he boiled the taro. When he opened the lid of the pot, the smell of the food made the man vomit all the rubbish he had in his stomach. All the stones and ginger and insects. Then taro shared the food and the man tasted a kind of savour he had never experienced before. He ate one piece and was full, so he took the other pieces from his plate and wrapped them in a leaf. When he left, taro gave him a nala surki, a 'day string', with knots that marked the number of days until their next meeting. The string had five knots. By the fifth day, he was instructed to clear an area of forest of trees and underbrush.

\section{The eye of the garden.}


Taro gardens are grown around a central planting which is the subject of much attention and care.

The 'eye of the garden' was first made by patuki, and he gave this way of gardening to Reite people. People who do not have this, our neighbours who patuki did not give this to, they do not have this. The people in the language groups around Nekgini, people higher in the mountains who speak N'dau, and the language groups that dwell on the coast itself below Reite lands, were not inhabited by the taro patuki and so they do not have these ways of growing taro. We see that many people plant gardens without this care and attention, yet they try and draw the spirits of the taro to their villages and their houses at the time of harvest. Reite people are confused by this, as they do not understand why you would plant taro without drawing on patuki and then think you could convince the spirit of taro to follow you from the garden. The places where the taro deity gave taro to people directly are in Reite. [Each design for the 'eye of the garden' (see below on kaap sernung) denotes a different story of the encounter with patuki.]

Back in the village (at a place called Yawaspiring), the man's wife and children became afraid because he had been gone so long. At dusk he arrived home, and when he opened the leaf containing food, they also vomited the rubbish in their bellies. After this, he shared the pieces of taro he had brought with him and they slept well for the first time.

Everyone else was still up all night boiling stones and unable to sleep from hunger. They noticed that the Reite man was able to sleep. Reite told them that on the designated day, he would tell them what he had. On that day they went to Piu'tapu, Taping Nomang and Piu'ising places. His extended family prepared the ground as instructed and the taro patuki came and piled up taro there. The variety was ouyuyuwing pel kapa. He also brought the varieties we call pel parieng, ('female taro'). Patuki cooked the taro in clay pots on the ground. When he took off the leaves that covered the pots, everyone vomited from the smell. He served them the taro and they ate it, and then slept that night for the first time. They followed his instructions and when the bush was dry, they burned the dry material and followed instructions to make the place called wating, the centre of the garden where he said he would hide. They divided the rest of the garden into hokung (sections), one each for all the people who had come to make the garden with him. For himself, he made the wating and said that only he would go into this central area. Next he brought them the other things to plant in 
the central area of taro gardens; yari mumosong, keta tokung'aring, tawau, upitapoli, siwinsing, usau anang, luhu (pitpit, sugarcane, aibica, variegated large leaf codyline, fragrant grass, sun bananas, and ginger (T.P. gorogor). ${ }^{\text {viii }}$ He instructed them how to plant these things.

The first thing to plant is kendang (mother taro). ${ }^{\text {ix }}$ This is planted at each side. Pel kapa is planted in between them in the middle. He gave them this advice and showed how to make the wating. Taro said that the hokung wating would be made for him and he would stay there and look after the garden. 'You will make a road for me and I will follow it into the garden [kaap sernung, 'spirit road']. You should make paths for me into the other people's hokung but no one else should be allowed into the central hokung where the wating is. Not your wives and children.'

To make the wating as shown in our drawings, first, dig the ground over. Then split a luhu (Tok Pisin, 'gorogor', Etlingera amomum [Zingiberaceae]) stem lengthways and surround the central area with the split stem. Everything else is planted within the stem. The man who gave us taro remains hidden, we make this central area to hide him in and we hum his name in the tune of his own voice to draw him into the garden. The wating then is the garden child's 'eye' or growing point, shoot.

At harvest, we bring this taro man with us to the village. First, we 'close the [spirit] road' of the garden (wa sasiret). This refers to the kaap sernung that bring the taro to the wating. The wating is the small central planting within the split ginger plant (T.P. gorogor). It is surrounded by the wasimung ('child of the garden'), in the very centre of the garden. It is called 'wa simung' ('garden child') because this area provides the 'child taro', the seed taro for the next year's garden. We say 'seed taro' (in Tok Pisin pupul taro) but they are not seeds, they are part of the same plant that generates its descendants by itself. This area is enclosed by the 'kaap sernung', the 'spirit road'. Other sections are planted for other people outside this road and generally called hokung. This road must be blocked to keep the taro in the garden. We close the road, then specifically show a route for the taro to come and bring its strength to the village. Each place has a sign of specific leaves or fruit. These are placed on the path and along the road from the garden to the village along with taro leaves to show the way. This pattern is clear in the drawings but notice that the shape made by the kaap sernung is different. All wating are the same in design and shape, and all are surrounded by 
the wa simung, the garden's child, but the shape of the wa simung depends on the design of the kaap sernung, the road that brings the spirit of taro into and out of the garden. The wating is always planted on the lower edge of the wa simung, with the rest of this area above on the slope.

Reite Yawaspiring make their kaap sernung to create the shape of the spirit pool (where taro was revealed). The design is called tupong aluling (Figure 2, Figure 3). No one else is permitted to use this design if they are not given it by Reite Yawaspiring for their garden as it references the specific connection between Reite Yawaspiring place/people and the pel patuki, the revelation of taro. This was the instruction of the taro patuki.

When the first garden was ready, the taro was harvested and taken to the village. The corms were cleaned in the garden, and then their leaves were collected and placed on the road to the village as they went. The taro was piled in the village, and the next day, everyone in the area was invited to come. Pel kapa was the taro variety given to Reite, other varieties were given to other places. Corms and seed corms were then distributed to the different people who arrived. Reite people say they kept the good taro varieties for themselves. They gave instructions for planting of the gardens, the time of year for each to start and each to harvest, the way to clear the bush, and to plant the wating. The general design for the kaap sernung around the wating was distributed at this time (Figure 2). This general design is the one used by most people (for example, many are now connected to the taro patuki through Reite Yawaspiring).

The people from [the hamlet of] Marpungae came late in the day. ${ }^{x}$ By this time only the female taro variety kotung pel was left. Marpungae people have become used to growing taro from poor and small seeds, and still succeeding with their gardens. Marpungae have their own design for the kaap sernung which comes from the lower edge of the whole garden and arches over the wa simung before dropping back to the edge in parallel with the upward path. This makes the downslope side of the wa simung open, and the wating resemble the jaw of a man, so the whole resembles a man's head (Figure 5).

There is one more design for the wa simung that Serieng Watupang brought and gave to Reite Nalasis. This we call kau atting 'crayfish leg' (Figure 1). The illustration of the newly planted garden shows this form. The kaap sernung loops around the wa simung from the bottom of 
the garden. The road is thinner in places, and fatter in others, just as the legs of freshwater crayfish are. In this drawing you can easily observe how and where the kaap sernung enters into the other hokung of the garden with small entrance paths coming off the main route. All kaap sernung have these entrances to each and every hokung in the garden, for the taro to watch over the growth in each.

In the wating, people look for an indication of the health and growth of the whole. When the wating is planted, a coconut is cut and people ask that insects will not come into the garden and damage the leaves of the growing plants. Taka talaert upayuwing (break coconuts for him). The coconut is wrapped in the leaf of luhu (tok pisin, 'gorogor'), the plant that is used to stop anger, fights, and to protect people and plants from malevolent spirits and forces. When the coconut is split, it gives an indication of the future health of the garden. A clean break is a good sign, a break that is jagged suggests the that there will be problems. A piece of the coconut husk and the gorogor leaves are buried at the base of a yam or banana plant within the wa simung. Gorogor wards off malevolence, and thus also the jealousy or anger of other people which could stop the garden growing well.

[[insert image 1 around here]]

Image 1: Porer prepares the Wating, Mayaparung, 2017.

The next stage is to plant the rest of the garden, including yams and bananas. It is necessary to plant everything at this point until the garden is complete. As soon as the wating and wa simung are complete, it is time to ask anyone else who has a part of the garden (a hokung/section) to come and help plant it the next day, just as Reite did in the first instance.

Aibica is the Tok Pisin term for a green leafy vegetable with lots of viscous sap (Hibiscus Manihot). Taro advised us to plant it in the taro garden. We plant it with the name of puing kamuning, the large morning star that appears before dawn. This will make the garden damp, and thus the growing shoots of taro and yam will be damp and green. Puing kamuning is a design that is also used to decorate the headdresses Reite people carry during ceremonies involving the spirits of the male cult, the first appearance of which was the voice of the taro patuki. When everything is wet with dew just after dawn, it is because Tawau/Aibica calls for the water for itself and refreshes the whole garden. 
Usau Anang (sun banana), pel kapa, and pel paring Kendang are all planted with the names of their patuki. Each has their own name. Patuki explained that making a special area for him and these other patuki means they can look after the garden and make it grow. Usau anang will make the sun shine on the garden, but it will not burn the young plants. This banana keeps the garden cool and so it is the one that everyone plants in their taro garden. Without this banana, the ground will dry out and even aibica would not be able to keep the shoots moist. Pitpit (edible cane grass) and sugarcane are planted in the wating for the taro spirit, and as he helps his own plants to grow, he helps the others in other hokung to grow. Puti is the bean that the taro patuki used to dry the water in his pool. The first time that people smelt taro cooking and vomited, they ate this bean and their sickness disappeared and they were able to eat taro. Cucumber, and ground cucumber were also among the vegetable specified by the taro patuki. Those of us who plant the wating do not eat cucumber and melon from other gardens as part of what it is to know the names of taro and yam.

At initiation, it is the mother's brothers who pass on their names for the patuki to youths. These names come with advice and guidance. They must give up eating freshwater crayfish (in case the taro shoots turn red and die); stonefish (the plants will move about and never root properly); fish from the sea (yams will grow to close to the surface and waste away); the tree vegetable asisang ('tulip' in tok pisin; Gnetum gnemon) as too much division of the leaves will make them weak. All of these food items fell like leaves from the tree that brought taro. When you are introduced to the name of the taro in order to grow good food, you must avoid them for fear of offending the taro. When a boy pays attention to his relationship to taro in this way, and everything grows well and is harvested, then he will give a yungyung (presentation) to whoever gave him the names. This presentation is of all the foods listed above, alongside good taro. In this way, you show your appreciation, the giver is happy, and the understanding of how to grow taro will 'stick' with you. (It seems that the patuki becomes one with the giver of his name, his previous presence in the garden. That is, the boy looks after his relationship to the taro patuki through and as the $M B$ who bestowed the name).

It is the responsibility of those who know the name of the taro to plant it. They are also responsible for following taro's instructions to collect earth from the wating and infuse the rest of the garden with it by throwing it to the four directions while calling the name of the grassland eagle, birds that all glide together at the same height, to encourage all the leaves to 
grow together equally. They collect saapung teti, and lodge it at the top of the dry trees in the garden. Saapung teti is 'cloud grass', and the taro will reach for the clouds.

\section{Yam planting}

Yams are a vital and important food for Nekgini speakers. They are also from ancestral times and have a patuki, the narrative of which is as follows: At the time before taro, a man used to sleep and while he slept, he would become a yam. His family was hungry so they used to pinch at his skin hoping to get something to eat. When he awoke he would find he was bleeding from all these places where he had been pinched by his family. He told them that if they wanted it so much, he was going to leave them and become a yam. He also gave them instructions about what to plant with him and how to look after him.

Yams are not planted in the wating but they are planted elsewhere in the taro garden. These yams send their shoots up dry trees and make huge 'houses' for themselves of foliage. Ring barked trees are left in the garden for them to climb, and the abundant rich dark green of their houses shades the plants in their vicinity.

We look for the point in the yam's body where the white flesh turns red and cut it at this point.

[[PLEASE INSERT IMAGE 2 ABOUT HERE]]

Image 2: Cutting a yam to retain the 'head', Reite 2019.

We plant this upper part ('head') and tell it that we putting it in its own house, saying something like: petwinia pang se awarr tanget palem e'nginia, se awarr taget koratt iri -'cut this stone to make a bed, and sleep here.' This refers to se awara, the limestone reef stone that is in the original place of the yam story, where he turned from man to yam. You name this place (Petwinia pang) and tell him he is making his house here. This refers back to the yam patuki, where the yam man slept on this bed, and his wives and children used to pick at him to eat. He is invited to make his bed in the garden and to sleep and become yam again. You plant this and hum the tune of the patuki mokati, this is the voice or tune of the yam patuki. When he hears it, he will feel sympathy with you and follow your wishes. 
Mokati is the name of the voice of the yam patuki. Those who know this patuki will also hum the tune slightly differently and make another tune/spirit appear while holding the shoot of the yam against the tree and telling it to climb upwards quickly.

\section{[[PLEASE INSERT IMAGE 3 ABOUT HERE]]}

Image 3: A vigorous yam shoot.

This tune is called Aiseer. It is different from Mokati. Aiseer is the name of a small lizard with a bright blue tail. He rushes up trees, and in this case, pulls the yam shoot with him as he goes. Aiseer is the person, the patuki, who does this. He is as a person. When we want something we ask for it and watch as he makes it well. His sympathy for us is the same as ours for him. We like the shoots of taro and we like the shoots of yam in the same way. But the two people we call on to help are different for each species. For yam, we tell him to lift stones and lift tree roots and make himself his bed.

To help with this, we gather plants that have characteristics and qualities that we wish to grow into our yams. These include long leafed epiphytes to encourage length, perfumed plants for sweet flavour, plants that resist insects and themselves have strong and vigorous growth. ${ }^{x i}$ These are shredded into powder and early one morning before anyone else notices, you bury this powder at the head of each yam in the garden with the same names and tunes as when it was planted.

[[PLEASE INSERT IMAGE 4 ABOUT HERE]]

Image 4: shredded plants for the Wating, Mayaparung, 2017.

Mokati is the source of earthquakes, he shakes the earth and makes it soft and broken up, making it easy for the yam to grow through. People collect the red flowers of the vine raaning and leave them in trees situated at the top of the garden, outside its border. The flower is told to stay out of the garden: 'your maternal uncle is there, keep out'. This prevents the small yellow insects that feed on the yam shoot from destroying the crop.

Yams are also something we are really interested by. The shoot is very small at its base, but as it climbs it proliferates exponentially and covers the trunk and limbs of trees nearby. When we see this thick foliage, we know it will make a large tuber and we like to see this. When we see the ground breaking in places a long way from the vine, we are happy to see this. 
When you have taro and yam, you are wealthy.

\section{Exegesis}

This section departs from the previous in that 'exegesis' is clearly only necessary for the articulation of elements otherwise taken for granted or left unarticulated by the story teller above. In this, it is rendered more directly in a comparative and analytic language used by an academic author. Nevertheless, it represents the discussion and elaboration that took place in the conversation at this point.

Taro and Yam do not grow by themselves. They are always part of and embedded in other relationships. Just like people. The creation of the garden has several themes we wish to draw from it and elaborate.

Firstly, the idea of sympathy and empathy (sori, in Tok Pisin). Food crops are kinds of beings that have feelings of sorrow and care for people. The work described above, interlaced as it is with knowledge and story, is about eliciting growth and sympathy, not imposing form. Whereas Peter Lawrence $(1964,17)$ described Madang people's relations to their deities as one involving coercion, we see something different here. As plants are already kinds of person, beings able to respond and reciprocate, there is also no sense here of the gardener imbuing or enhancing the plants with 'spirit'. They have spirit and responsiveness as part of their being. The taro story explained how to tend to the needs of other beings that also grow with and alongside people as part of their kinship and history. There is an interesting elision between the taro patuki and the Reite man who discovered and cared for him. Just as with the yam gardener, being related to, sharing substance and knowledge, and being the same as are closely allied here. Reite is the origin of taro, Petwinia Pang is the place where man became yam. The correspondences are of shared history and substance.

So the Reite taro gardener directs his thoughts and actions toward the taro patuki who is growing the garden. Gardener and deity work reciprocally, following the requests of the other. Taro is grown in this Reite form and not another. This is not superstitious sympathy magic. Rather, the images of what the garden is imagined as, the form that it takes to be beautiful, are expressed and brought into the garden with these words and actions, to which 
there is a response. Beauty, aesthetic form, is directly consequential on the growth of taro and yam. To give the garden the right form is to follow these processes that shape peoples' interactions with the plants and also shape how they feel and act with the harvested produce. The care shown in attending to the different aspects of growth and health are present in the images and language of mythic ancestors and birds and animals. It is this care that brings appreciation of the produce and appreciation of those who produce it. Shepherding, guiding, attending to, appreciating -- all important for the growth of children, are present in the care of these plants. There is then an interlacing of music, spirits, plants, people, history, and growth into a 'beautiful' process of creating and recreating the Reite world, including the male cult, myth etc. We draw attention here to the aesthetic that makes these actions part of the same action. If 'art' is a quest for grace and grace is the integration of mind, as Bateson proposed, the skill of the gardener is very apparent. Growth itself is the art of bringing these elements together.

The process of growing people is the process of growing yam and taro. There is no absolute difference in kind, only in form and appearance. Hence the possibility of replacing bodies with yam and taro effigies, as Reite people regularly do in compensation payments for bodies (see Leach 2003, 77-9). Reite people value persons and family above all else. They are as passionate and vivid in their protection and care for each other as they are in their disputes over rights and debts owed. For them to accept an effigy of garden food as a substitute body indicates the connection between persons, bodies, and gardens. The effigy is made of the same substance as people, and the same effort that goes into growing people has been shown by the yam and taro and their gardener. We also can discern that spirit is not a human exclusive. It is not that human spirits inhabit plants. Rather, they are transformations of each other. Reite gardeners talk to the garden and its elements like they are children. That is, they are 'bringing up' the garden through example, through encouragement, through guidance, and through images of how they should be. The constant attention to the garden in the form of these 'ritual' interventions, bring people to the garden, to tidy and weed it, etc. The rituals are the processes of making, bringing into being. And what is brought into being is a whole world of people and plants in the specific configurations that are recognised as 'Reite'. Recognising this, we can turn to the elements that are perceived and recognised as good and beautiful, thoughts about satisfaction among these gifted gardeners. You will see, these are also focussed on growing people. 


\section{Growing gardens: Growing people}

Urufaf and Porer continued with the following observations.

Our fathers tell us to respect our bodies and follow their advice and we will grow well. Everyone will look at you and feel pleasure and desire and appreciate your growth. It is the same for the garden. When we care for it well, it will grow well and look good. When a child is well brought up, everyone will look at them and find them beautiful. When they misbehave, don't eat well, don't listen to advice and do bad things, then everyone will see this and not think they look beautiful at all. It's the same for the garden. If the gardener does not follow these ways of doing things, does not care properly for how the garden looks, how it is planted and what goes into it, no one will think it looks beautiful and it will not grow into its beauty.

When it is time to make a large ceremony, we tell the garden, saying 'turum maliem katuketa kot yara pel'ang a kurring erangi' (we are preparing for a ceremony and you must shake your leaves and grow well). With this, we are also telling ourselves not to be lazy in making the steps and techniques to make things grow properly. When we ask in this way, for this reason, gardens always grow well. It motivates the garden and the gardener to do everything they can to make the taro grow smartly. We view the shoots of the plants with the same pleasure as we have looking at growing children. And when we 'close the road' of the taro before harvest, we ask the taro patuki and the taro mother to look after their children.

It is clear, taro is a man. Everything we do in the garden for gathering the produce for a ceremony, everything bears the mark of a man. It is true that we repeat over and again that the mother and father must care for it. That is very true. It is this same man (patuki) that made everything. Patuki made men, he made yam and taro, he made the first ceremonial decorations and the first ceremonial effigy (palem) from the fruits of the garden. Patuki exists in all of them. Thus, patuki told us that when the garden is ready to eat, you should take me with you to the village. When you do this, take leaf taro and put it on the path, and he will follow you to the house. Life must be brought along with the plants.

We like to look at things that grow well. Children are beautiful, and so are gardens. We make the wa simang, the garden's child, and we like to look at it. Our saying 'do not banish children' is as much for the garden, where we ask taro and yam to stay and grow their 
children, as for the household. So when we come to harvest taro, we make a special effort to convince the mother and father patuki's to keep their children with them in the garden. When it grows well we see that these people have heard us and have done as we asked.

A garden looks good to us when all the shoots emerge vigorous and strong, not eaten by insects. The other plants will also be smart and straight. It is attractive to the eye. When it is still young and tender, you will be very attached to it, and worry for its health. It is the same with initiates. You put your children in the shade and when they emerge you will feel happy. After this as they grow, you will enjoy the look of them. Just the same as a decorated ceremonial pole we make called tse'tsopung. ${ }^{\text {xii }}$ When you decorate it well and it has a healthy shine, you will want to be close to it and look after it. We like to look at it. It is the same. Yam and taro are similarly attractive to an initiate that we decorate well.

Once the garden is ready to harvest, it already looks old, but the food will be there. If you are happy when you see the taro grow well, equally you will be unhappy when it is ruined in some way or another. Talep samurlung is an old garden in Reite. When you have been taking food form a garden, it starts to mature and become old, but because of the care we take to look after the children of the garden, it remains for many months. We even say to the taro 'if they mistreat you elsewhere, come and be looked after here!' At this time, we also start thinking about the early gardens for the next year.

After a young man is married he develops the body of a man, and eventually becomes lazy or jaded and not full of vigour and energy like a young man. The garden is the same. When it becomes yellow and brown, you will be interested by its food, but not care much about the leaves and shoots. At this moment we also take the baby taro from the sides of the old corms, and make ready for next year's planting.

Why do we like to look at gardens growing well? We have a great interest and joy in looking at gardens! We say, 'Don't harm you wife and children. Take a wife and look after her and your children!' It is thus: we like things that are good for men and women, and it is the same for the garden, just as it is for when we decorate the village or our bodies for ceremonies.

In this context, Urufaf reminded us of the exchange he and his brothers achieved in 2018 . He explained that the ceremony was in celebration of the first successful taro gardens of his two 
elder brothers. They decided to invite a large number of people to come and receive gifts of taro and pork because they thought the taro had grown well and was looking beautiful. At that ceremony, Urufaf's father, Anip, explained that he was showing that he passed on the knowledge and strength he had to plant taro, and it grew beautifully, so they felt joy and pleasure. They wanted to share that joy with other people -- affinal, maternal, and other kin. The decision to make this 'free' presentation was a celebration of the beauty they achieved in the gardens last year. ${ }^{\text {xii } ~ ' W e ~ a s k e d ~ p e o p l e ~ b e y o n d ~ o u r ~ i m m e d i a t e ~ f a m i l y, ~ m o t h e r ' s ~ b r o t h e r s, ~}$ mothers and cousins, so that they would have good thoughts and happiness with us in our success. It was possible because we followed the ways of taro, the taboos and the restrictions. We gave yungyung to the father who passed on the taro names and designs. The taro grew well for this reason. Seeing it grow well made us happy, and that also prompted us to give it away so others would keep good thoughts about us.'

\section{[[PLEASE INSERT IMAGE 5 ABOUT HERE]]}

Image 5: 'Maliem yungdu', 'Well fed people have good thoughts, and the garden will grow well again.'

When patuki made the first garden, he gave sections to everyone in Reite. We still follow this way. When each harvests their section, they must take the first taro and some meat to the owner of the garden, who has planted the wating. Then he can harvest food as he chooses. It is the owner of the garden who cares for the wating and the wa simung, and thus who grows the food in everyone's section of the garden. This is why he must be given the first taro. He is responsible and he is the only one who enters the central parts of the garden. It is so there is no disturbance to the growing plants. In fact, we do not approve of disturbance in gardens, throwing stones, shouting, or arguing. It is in this central space that the owner of the garden can talk to patuki.

\section{Conclusion}

The descriptions of Porer and Urufaf are full of poetics, descriptions of the connections, history, and reasons for making gardens in the way that they do. James wishes to highlight the metaphorical and poetic. For one thing, in writing the paper with Porer and Urufaf, it became clear that the uses of language and metaphor, the poetics, are not different from the practical and technical aspects of garden creation. 
An effect of presenting the Reite garden in this manner is to allow the quite beautiful attention to the unfolding of growth and process, the satisfaction of being part of the process and cycle, to stand for itself. It offers a glimpse of the way the material and the process are one with the 'meaning', and what is achieved as a regular transformation of relations with past, present and future others through the growth of the garden. In this regard, it is helpful to mention recent work which points to the regenerative capacity of staple crops in Melanesia.

Strathern $(2018,14-17)$ has pointed out that yam tubers, and taro corms, self-replicate. That these plants reproduce through a kind of cloning, where the same plant that is eaten is also (in part) replanted and continues to grow into the next year's harvest. In this way, yam and taro are the same yam and taro that persist, in relations to particular gardeners, through many human generations. She links this to the notion of immanence: that life and regeneration are immanent in relations between plants and people. There is no need to consider life or spirit or soul as transcendent and added to matter. Rather, matter itself is where life/spirit is perpetuated.

The Reite art of gardening recognises the correspondence in growth and the interdependence of people and plants. This is elaborated in great depth by gardeners who are also expert and skilled growers of people. Many things in the Reite world are 'people'. This does not mean they are 'animated' from outside as it were by magicians or ritual specialists. The magic and ritual shapes and foregrounds the correspondences, it makes visible and thus perceptible the value and beauty or power of forms that participate in cycles that keep the process of life going. In another context, Strathern $(2013,24-25)$ once wrote,

An indigenous visual theory? It turns out to be a theory of practice, programs or recipes for action. We shall find ourselves needing to confront notions of personhood, affect, power. We may even find ourselves looking at what we could call social technology, technologies of the self that are technologies of relationships.

This returns us to Bateson's conceptualisation of grace, which is not explicitly a religious one. His argument is that the mechanisms of perception and thought cannot all be conscious to the perceiver or thinker. Unconscious processes are necessarily at work in any mind. The development of skill is the development of habitual and therefore unconscious mental and physical processes. Skill allows a level of what he terms 'redundancy' -- meaning the 
predictability of sequences of information -- where aspects lying outside consciousness, pattern the whole. Skill amounts to utilising the quality of redundancy to integrate information in higher order levels of communicative economy -- redundancy -- facilitating or bringing into being multiple aspects of transformation in the same perception. Art is an example of skill that he uses, as art's messages are not only about what is brought to consciousness in the image or performance. It relies upon high levels of redundancy, pointing towards transformations that integrate multiple levels at the same time. He calls this integration 'grace' as discused above. This conceptualisation of 'art', 'skill', and 'grace' is a possible way of moving beyond an interpretive approach to gardens as high art or symbolic communication in this context. It enables a highlighting of the processes which the gardener in Reite brings to collaboration with plants, myth, people, soil, climate, and history.

The satisfaction of the garden artist in Reite is that his skill, which is both conscious and unconsciously built over time, results in a meta-level communication about the relationship of the gardener to the world creating and life-giving powers of deities that are also himself. And here is where the correspondences come in so forcefully: because they are real. The growing of crops is the growing of children. The same joy occurs when one contemplates either. Both demonstrate skill and capacity of which there is a mystery that remains, and that mystery is also corresponding. The patterns and the resulting redundancies are operationalised by the skilled activity of gardening. Of knowing the taro patuki, of following his procedures, of thus engaging also with spouse and siblings, affines and enemies. The successful and growing garden sends complex and deep messages, only some of which are verbalised (taro is growing well et cetera). The same in reverse, a ruined garden or a poor harvest are also meta messages about the relations the gardener has to others. As Bateson $(1972,138)$ has it,

the message of skill of any sort must always be of this kind. The sensations and qualities of skill can never be put in words, and yet the fact of skill is conscious.

The correspondence between human life and growth and plant life and growth are deeply understood, motivating, and a source of desire. Yams are seen as beautiful and successful when they are large and heavy, Taro when it has bright skin and deep colour. The source of these qualities is in the work of organising and realising connections. The plant/human correspondences are clear in their commentary on what is found satisfying and beautiful. 
'Children are loved and grown by their families and they bring pleasure and we find them beautiful. This is the same as our gardens.' Growing children is continuing the possibility for taro and yam to grow as each are tended and renewed by those others that care for them.

\section{References}

Bateson, G. 1972. Steps to an Ecology of Mind. Chicago and London: Chicago University Press.

Lawrence, P. 1964. Road Belong Cargo: A Study of the Cargo Movement in the Southern Madang District, New Guinea. Melbourne: Oxford University Press.

Leach, J. 2003. Creative Land. Place and Procreation on the Rai Coast of Papua New Guinea. Oxford: Berghahn Books.

Leach, J., and R. Davis. 2012. "Recognising and Translating Knowledge: Navigating the Political, Epistemological, Legal and Ontological”. Anthropological Forum: A Journal of Social Anthropology and Comparative Sociology 22 (3): 209-223.

Nombo, P, and J. Leach. 2010. Reite Plants. An Ethnobotanical Study in Tok Pisin and English. Canberra: ANU Press. http://doi.org/10.22459/RP.01.2010

Picton, J. 1992. “A Tribute to William Fagg”. African Arts 27(3): 26-29, 100.

Strathern, M. 2013. Learning to see in Melanesia: Lectures given in the Department of Social Anthropology Cambridge University, 1993-2008. Chicago: HAU Books, University of Chicago Press.

Strathern, M. 2018. "Souls in Other Selves, and the Immortality of the Body". Lecture for The Foester Lectures on the Immortality of the Soul, UC Berkeley, April 17, 2018) Wagner, R. 1975. The Invention of Culture. Chicago: Chicago University Press.

Weiner, J. F. 1995. “'Too Many Meanings': a Critique of the Anthropology of Aesthetics”. Social Analysis 38. Adelaide: University of Adelaide.

Young, M. W. 1971. Fighting with Food: Leadership, Values and Social Control in a Massim Society. Cambridge: Cambridge University Press.

\footnotetext{
i I thank the anonymous AF reviewer for their concise and helpful formulation of the notion of 'grace' in Bateson's writing, and their further confirmation of its interest when approaching the drawings and text presented here.

ii James is grateful to Jean Mitchell for expanding my understanding of 'satisfaction' by drawing my attention to this etymology. https://www.etymonline.com/word/satisfy accessed 1/12/2020
} 
satisfy (v.)

early 15c., from Middle French satisfier, from Old French satisfaire "pay, repay, make reparation" (14c., Modern French satisfaire), from Latin satisfacere "discharge fully, comply with, make amends," literally "do enough," from satis "enough" (from PIE root *sa- "to satisfy") + facere "to make, do, perform" (from PIE root *dhe- "to set, put").

iii Everything that makes us human came from other people, and what created the world in its human, gendered form, also came from other places. These are all connected to us through the story of their origin.

iv See also Leach 2003: 119-123.

${ }^{v}$ That is Taro. See the yam myth below. The patuki is both the spirit and the tuber.

${ }^{v i}$ See Nombo and Leach 2010.

vii Paap, 'salt wood' a kind of porous wood collected on the seashore which when burnt produces a salty ash. Paap was a significant and rare valuable in ancestral times.

viii See Nombo and Leach, 2010: 81-94.

${ }^{\mathrm{ix}}$ There are male and female varieties of taro, distinguished visually by their shape and colour of flesh (red and rounded for female, elongated and white for male. Yams, however, are only ever said to be 'a man'.

${ }^{x}$ Urufaf Anip, our youthful third author, is a descendent of Marpungae.

${ }^{x i}$ See Nombo and Leach 2010: 95-97.

xii See Nombo and Leach 2010: 46-47.

xiii 'Free' in the sense that it was not part of any other obligation (for example, bride payments, or initiation payments). 